\title{
Continuous-flow microreactor multi-step synthesis of an aminonaphthalene derivative as starting material for the preparation of novel anticancer agents
}

\author{
Lutz. F. Tietze* and Deshan Liu \\ Institute of Organic and Biomolecular Chemistry of the Georg-August-University Goettingen \\ Tammannstr. 2, 37077 Goettingen, Germany \\ E-mail:1tietze@gwdg.de
}

Dedicated to Professor Arlette Solladie-Cavallo on the occasion on her $70^{\text {th }}$ anniversary

\begin{abstract}
A multi-step synthesis of the aminonaphthalene derivate $\mathbf{1}$ as a key intermediate in the synthesis of the duocarmycin based prodrug 2 for a selective treatment of cancer in a microreactor is described. The conditions for the synthesis in the batch mode were adjusted for application in a microreactor and the results of both methods were compared showing that the transformations in the microreactor in most cases give similar or even better results with the advantage of a continuous-flow production, higher safety and faster reactions with an empirical accelerating factor of $F=3-10$.
\end{abstract}

Keywords: Biphasic reactions, continuous flow reaction, Friedel-Crafts acylation, microreactor, olefination, Curtius rearrangement

\section{Introduction}

A microreactor (MR) is a miniaturized reaction system fabricated using microtechnology and precision engineering, which generally contains a small reaction volume in the nano- to microliter range with characteristic microchannel dimensions between ten and several hundred micrometers. ${ }^{1}$ The use of microreactors in the synthesis of chemical compounds is of high interest not only for research but also for production, as reactions in microreactors have several advantages over those in the usual equipment. When two or more different fluids are introduced into microreactors, a laminar flow will dominate. As a consequence from miniaturization, the molecular diffusion path is reduced and the diffusion-controlled mixing is significantly accelerated in a way that mixing goes to completion normally within milliseconds to a few seconds at the most. ${ }^{2,3,5}$ Moreover, due to a highly efficient heat transfer hot spots do not occur 
and thermally induced undesired side reactions are effectively suppressed. Thus, microreactors are especially useful for very fast and highly exothermic reactions. ${ }^{3,45}$ In addition, the continuous processing ${ }^{6}$ has an inherent operational safety and an economical advantage, since the synthesis of large quantities of a product can be done by numbering-up the reaction vessels instead of using a conventional time- and cost-consuming scale-up process. The use of microreactors is a subject of intensive research in industry, and one can expect that microreactors will be a promising alternative to the present chemical reactors in fine chemical production .,9a

On the other hand it should not be denied that microreactors still show several problems, ${ }^{8,9}$ which hamper their use. Typical among these is the chemical clogging of the tiny microchannels, since many chemical transformations involve solid handling or the formation of precipitates. In addition, multi-step syntheses using microreactors have so far seldom been reported. ${ }^{10}$

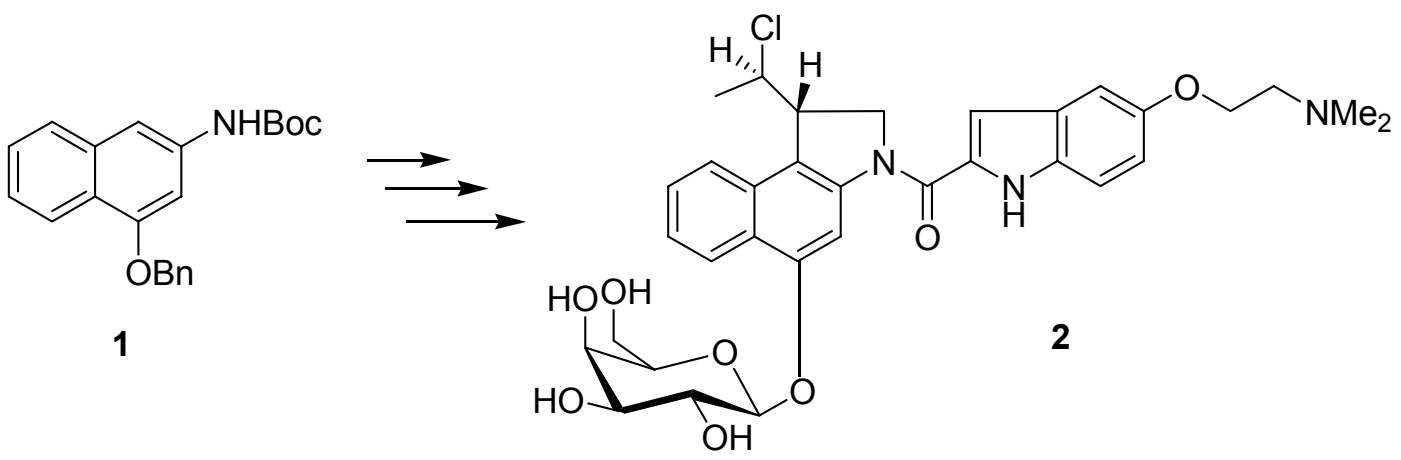

Scheme 1. Compound 1 as building block of prodrug $\mathbf{2}$ for a selective treatment of cancer.

In the development of the duocarmycin based prodrugs of type $\mathbf{2}$ for a selective treatment of cancer using the ADEPT approach (Scheme 1), ${ }^{11}$ the aminonaphthalene derivate 1 serves as an important building block and its synthesis has been carried out according to a classical route (Scheme 2). ${ }^{12}$ Due to the need of large amounts of the prodrug 2 for clinical trials an efficient continuous synthesis of $\mathbf{1}$ was needed to allow the preparation of $\mathbf{2}$ in a $\mathrm{kg}$-scale. We assumed that the use of a microreactor would open a reasonable way to achieve this aim with good reproducibility of product quality by precise control of reaction conditions in a continuous way. Here we report on a multi-step synthesis of the aminonaphthalene derivate $\mathbf{1}$ in a microreactor $\left(\right.$ CYTOS $^{\circledR 1} 13$ College, Figure 1). First we focused on the modification of the classical reaction conditions in order to allow the use of a microreactor by avoiding the employment and formation of solid material. At last the results using the batch mode and the microreactor were compared in respect to yield, reaction time and temperature. 

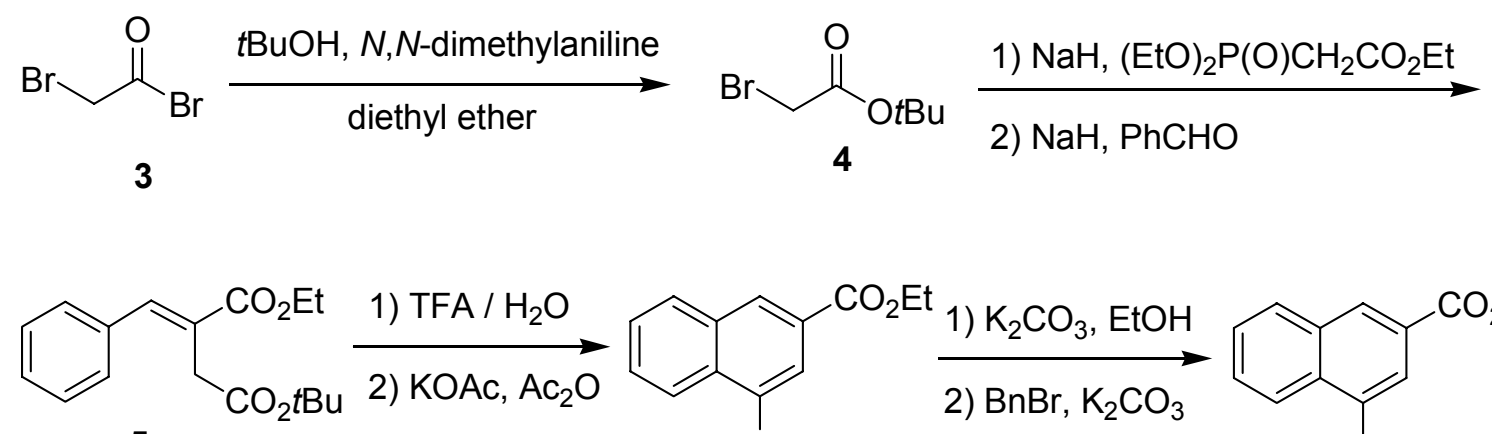

5
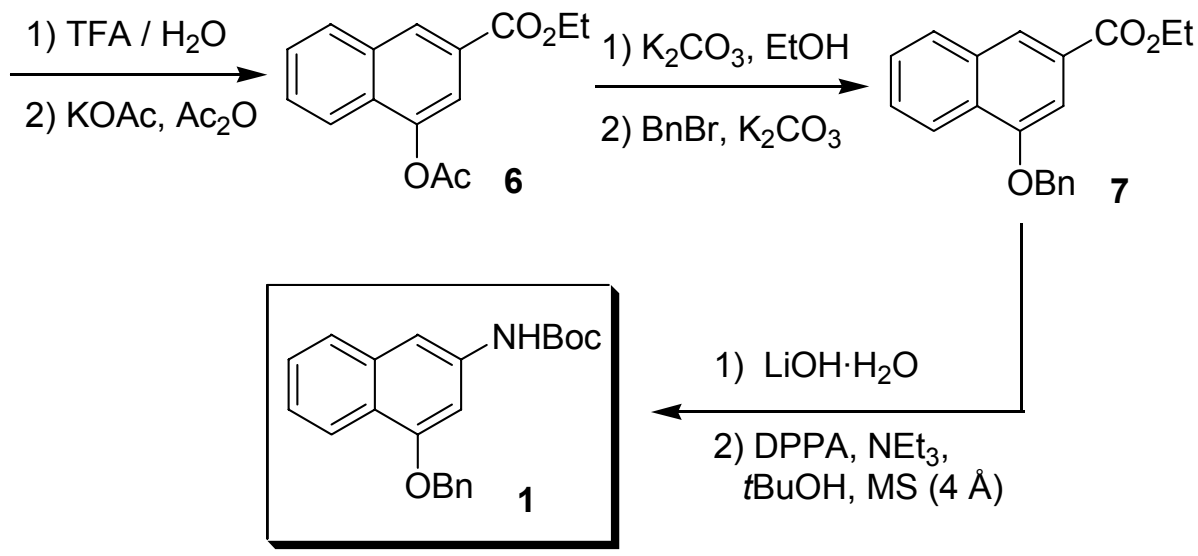

1) $\mathrm{LiOH} \cdot \mathrm{H}_{2} \mathrm{O}$

2) DPPA, $\mathrm{NEt}_{3}$, $t \mathrm{BuOH}, \mathrm{MS}(4 \AA)$

Scheme 2. Classical synthetic route of the aminonaphthalene derivative $\mathbf{1}$.

The following symbols are used, $t$ : reaction time in the batch mode at a given reaction temperature; $\tau$. residence time in the microreactor (residence volume / total flow rate); rt (room temperature): $22-25^{\circ} \mathrm{C} ; T$ : reaction temperature in the batch mode (internal temperature) and in the microreactor (controlled by an external thermostat); $F$ : empirical accelerating factor which characterizes in which extent the use of a microreactor can accelerate a chemical reaction, defined as $F=t$ (reaction time) / $\tau$ (residence time). It should be noted that throughout the manuscript the given $F$ values are only estimations, since an exact determination of the kinetics of the transformation using GC has not been performed. Furthermore, the given yields for the transformations in the microreactor refer to the results under steady-state conditions; thus, the production before that time is usually lost, which however is of no importance, if the total production time is much longer than the start-up time.

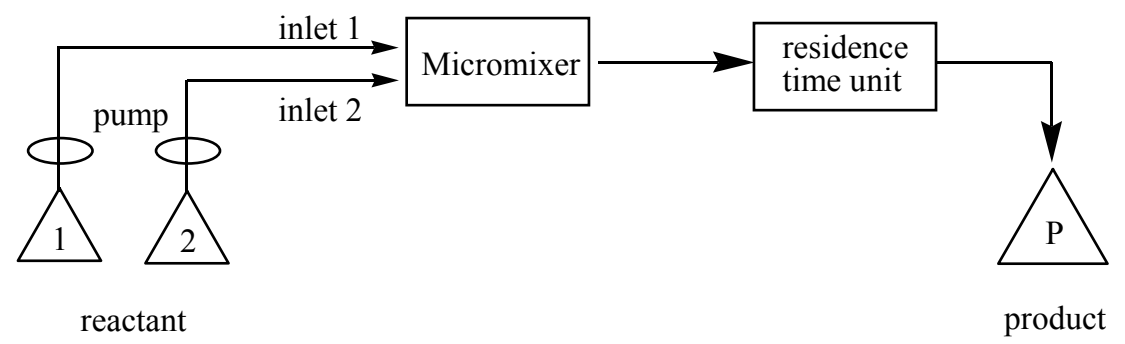

Figure 1. Microreactor system $\left(\mathrm{CYTOS}^{\circledR}\right.$ College, heat exchanger not drawn here). 


\section{Results and Discussion}

For the synthesis of the tert-butyl ester $\mathbf{4}$ using the bromoacetyl bromide $\mathbf{3}$ as starting material the solvent diethylether employed in the batch mode was not suitable for the microreactor due to the formation of an ammonium salt as precipitate. ${ }^{14 \mathrm{a}} \mathrm{THF}$ proved also not to be appropriate due to a side reaction with 3. ${ }^{15}$ Among other solvents investigated as $\mathrm{CH}_{3} \mathrm{CN}$, DMSO, $t \mathrm{BuOH}$ and $\mathrm{DMF}, t \mathrm{BuOH}$ and DMF showed an overall homogeneous reaction with moderate to high yields (Table 1, entry 2-4). The use of $t \mathrm{BuOH}$ as solvent afforded a yield of $81 \%$ in the batch mode within $20 \mathrm{~h}$ at room temperature, whereas in the microreactor with $34 \mathrm{~min}$ residence time at $25^{\circ} \mathrm{C}$ only $50 \%$ yield of 4 was obtained. It is possible to increase the yield by reducing the total flow rate to prolong the residence time, which however is less desirable due to a lower efficiency and limited flow rate control. The addition of catalytic amounts of DMAP as additive did not improve the conversion neither in the batch mode nor in the microreactor (entry 2 and 3); thus, under these conditions after $5.5 \mathrm{~h} 4$ was formed in the batch mode in $43 \%$ yield. A better result was obtained employing DMF as solvent with 34 min residence time using catalytic amounts of DMAP and a reaction temperature of $35^{\circ} \mathrm{C}$ to give 4 in $66 \%$ yield. A comparison of the reaction rates under the different conditions revealed that the transformation in the microreactor proceeds with an accelerating factor of about 10 .

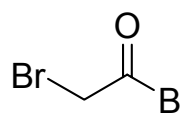

3
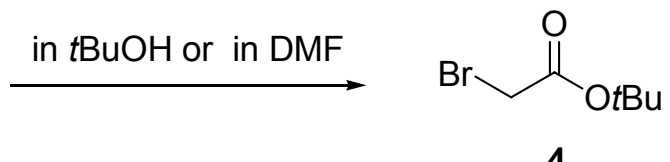

Scheme 3. Synthesis of the tert-butylester 4.

Table 1. Synthesis of $\mathbf{4}$ in the batch mode and in MR: [a] Isolated product by distillation. [b] Dry dichloromethane was used to dilute $3(V / V=1: 1)$. [c] Reaction without addition of DMAP

\begin{tabular}{cccc}
\hline Entry & Solvent additive & Batch mode yield ${ }^{[\mathrm{a}]}$ & MR yield $^{[\mathrm{a}]}(\tau, T)$ \\
\hline $1^{[14 \mathrm{~b}]}$ & $\mathrm{Et}_{2} \mathrm{O}$ & $78 \%(4 \mathrm{~h}, \mathrm{rt})$ & - \\
$2^{[\mathrm{b}]}$ & $3.0 \mathrm{eq} t \mathrm{BuOH}$ & $81 \%(20 \mathrm{~h}, \mathrm{rt})$ & $50 \%\left(34 \mathrm{~min}, 25^{\circ} \mathrm{C}\right)$ \\
$3^{[\mathrm{b}]}$ & 3.0 eq $t \mathrm{BuOH}+10-\mathrm{mol} \% \mathrm{DMAP}$ & $43 \%(5.5 \mathrm{~h}, \mathrm{rt})$ & $50 \%\left(34 \mathrm{~min}, 25^{\circ} \mathrm{C}\right)$ \\
$4^{[\mathrm{b}]}$ & $\mathrm{DMF}+10-\mathrm{mol} \% \mathrm{DMAP}$ & $62 \%(19.5 \mathrm{~h}, \mathrm{rt})^{[\mathrm{c}]}$ & $66 \%\left(34 \mathrm{~min}, 35^{\circ} \mathrm{C}\right)$ \\
\hline
\end{tabular}

To prepare the phosphonosuccinate $\mathbf{9}$ and its anion $\mathbf{1 0}$ for the olefination of benzaldehyde $\mathbf{1 1}$ to give 5, sodium hydride is commonly used as base (Scheme 4). ${ }^{16}$ However, the intermediate 8 $(\mathrm{M}=\mathrm{Na})$ has a low solubility in THF and the by-product $\mathrm{NaBr}$ formed by the following nucleophilic substitution was almost insoluble in THF. On the other hand, LiBr dissolves well in THF, we therefore used the organic lithium reagents Li-HMDS, LDA and $n$-BuLi for the 
deprotonation. $n$-BuLi was most suitable to obtain an overall homogeneous reaction mixture and for that reason was employed in the microreactor (Table 2, entry 2-4 to give the desired compound 9 in a yield of $70 \%$ already after 24 min at $40^{\circ} \mathrm{C}$, whereas in the batch mode only $57 \%$ of 9 after $36 \mathrm{~h}$ at room temperature were formed. Other approaches using phase transfer conditions (aqueous $\mathrm{NaOH} / \mathrm{TBABr}$ ) or the combination of $\mathrm{LiCl} / \mathrm{NEt}_{3}{ }^{17}$ have failed completely.

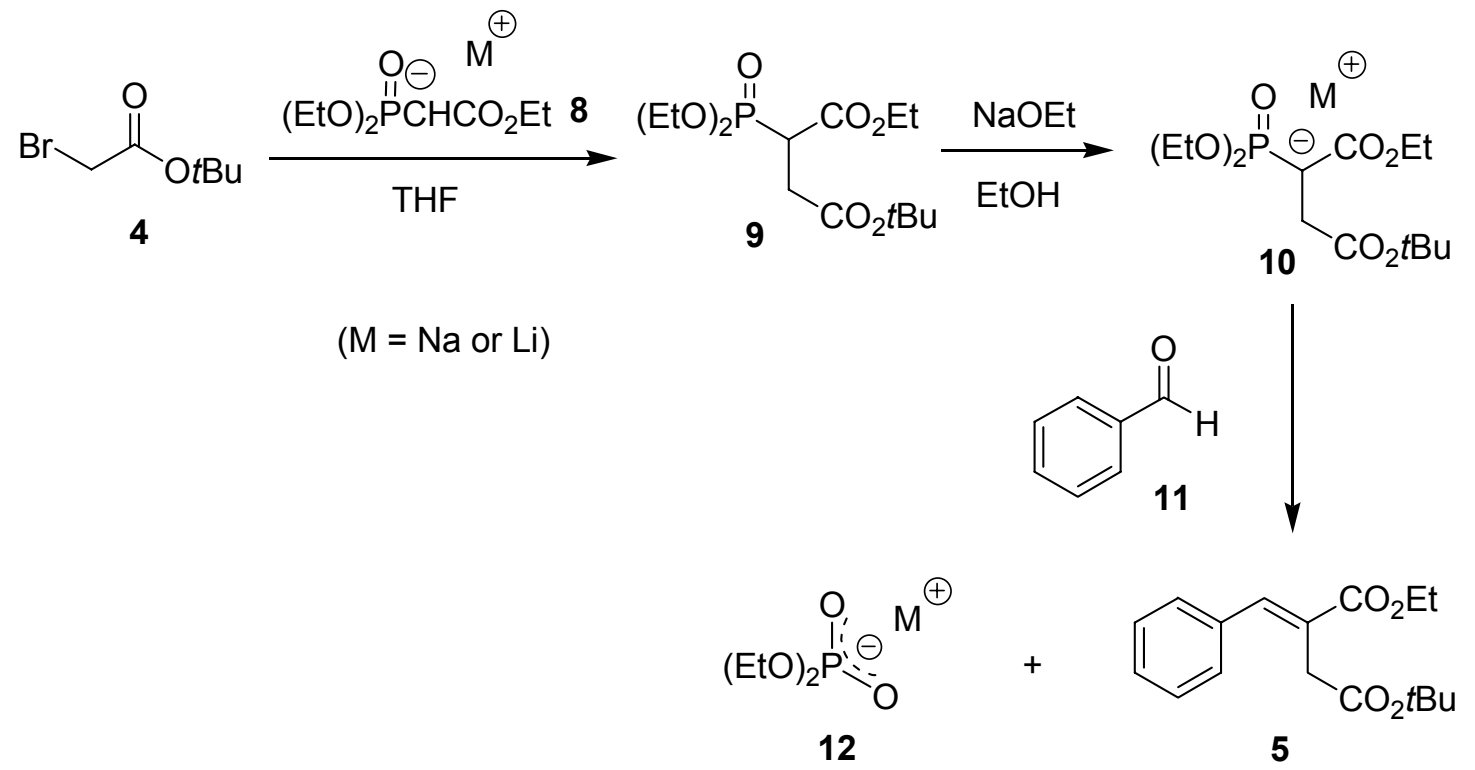

Scheme 4. Synthesis of 9 by nucelophilic substitution and of 5 by Wittig-Horner olefination.

Table 2. Synthesis of 9: [a] Isolated product after distillation. [b] Isolated product after column chromatography

\begin{tabular}{cccc}
\hline Entry & Base & Batch mode yield $(t, T)^{[\mathrm{a}]}$ & MR yield $(\tau, T)^{[\mathrm{a}]}$ \\
\hline 1 & $\mathrm{NaH}$ & $91 \%(24 \mathrm{~h}, \mathrm{rt})$ & - \\
2 & Li-HMDS & $87 \%^{[\mathrm{b}]}(12 \mathrm{~h}, \mathrm{rt})$ & not performed \\
3 & LDA & $70 \% \%^{[\mathrm{b}]}(15 \mathrm{~h}, \mathrm{rt})$ & not performed \\
4 & $n$-BuLi & $57 \%(36 \mathrm{~h}, \mathrm{rt})$ & $70 \%\left(24 \mathrm{~min}, 40^{\circ} \mathrm{C}\right)$ \\
\hline
\end{tabular}

In the following Wittig-Horner olefination ${ }^{18}$ conventionally performed in two stages, ${ }^{16}$ again we searched for an overall homogenous reaction. In the microreactor $\mathrm{NaH}$ and $n$-BuLi with THF as solvent could not be used, due to the formation of the in THF insoluble intermediate 10 (M = $\mathrm{Na})$ and the by-product $12(\mathrm{M}=\mathrm{Li})$ (Scheme 4 and Table 3, entry 1 and 2). Using DMSO as solvent with $n$-BuLi allowed a transformation in the microreactor at elevated temperature, but the yield was much lower as in the batch mode. However, the olefination using $\mathrm{NaOEt}^{19}$ in the microreactor gave a yield of $89 \%$ of the desired compound 5 with a residence time of 47 min at $25^{\circ} \mathrm{C}$, while a shorter residence time afforded a mixture of 5 and the starting material (entry 4 ). 
Compared to the batch mode the accelerating Factor $F$ is about 6. It is worthwhile to note that 5 formed in the microreactor has an excellent purity and that the reaction proceeds with high stereoselectivity; thus, the Z-isomer of $\mathbf{5}$ could not be detected (NMR). The in situ generation of the intermediate $\mathbf{1 0}$ seems to be very beneficial, since another approach in the microreactor using a separate deprotonation with NaOEt under otherwise the same conditions as in entry 4 afforded only a mixture. Noteworthy, for reactions in the microreactor the collection period is important. The following different yields were obtained using different times to start the collection (conditions, entry 4): Collection from $1.0 \tau$ over $21 \mathrm{~min}$ : 57\%, collection from $1.5 \tau$ over $20 \mathrm{~min}$ : $78 \%$, collection from $1.9 \tau$ over $30 \mathrm{~min}$ : 89\%. Obviously, even after a time of $1.9 \tau$ the steady state conditions have not been ensured, which resulted in an overall lower yield in the microreactor compared to the batch mode. Usually, a collection beginning time of $1.5 \tau$ is suggested. ${ }^{13 \mathrm{c}, \mathrm{d}}$

Table 3. Synthesis of 5: [a] Crude product. [b] Isolated product after column chromatography

\begin{tabular}{cccc}
\hline Entry & Base / solvent & Batch mode yield $^{[\mathrm{a}]}(t, T)$ & MR yield $^{[\mathrm{b}]}(\tau, T)$ \\
\hline 1 & $\mathrm{NaH} / \mathrm{THF}$ & $92 \%(12 \mathrm{~h}, \mathrm{rt})$ & - \\
2 & $n$-BuLi / THF & $84 \%(17 \mathrm{~h}, \mathrm{rt})$ & - \\
3 & $n$-BuLi / DMSO & $81 \%\left(11 \mathrm{~h}, 45^{\circ} \mathrm{C}\right)$ & $35 \%\left(54 \mathrm{~min}, 40^{\circ} \mathrm{C}\right)$ \\
4 & $\mathrm{NaOEt} / \mathrm{EtOH}$ & $97 \%(5 \mathrm{~h}, \mathrm{rt})$ & i) $80 \%\left(23.5 \mathrm{~min}, 25^{\circ} \mathrm{C}\right)$ \\
& & & ii) $89 \%\left(47 \mathrm{~min}, 25^{\circ} \mathrm{C}\right)$ \\
\hline
\end{tabular}

In the following acid-catalyzed cleavage of the tert-butyl ester function in $\mathbf{5}$ the neat substrate 5 as solid needed to be dissolved in dichloromethane as additional solvent. By this way it could be separately pumped into the microreactor to react with TFA. In the batch mode the addition of dichloromethane had no influence on the yield. The transformation is a fast reaction and was completed in just $5 \mathrm{~min}$ at $34^{\circ} \mathrm{C}$ in the microreactor (Table 4), which is in accordance with data from the literature. ${ }^{16 \mathrm{~b}, 20}$ 
<smiles>CCOC(=O)CC(=Cc1ccccc1)C(=O)OCC</smiles>

5<smiles>CCOC(=O)c1cc(O)c2ccccc2c1</smiles>

14

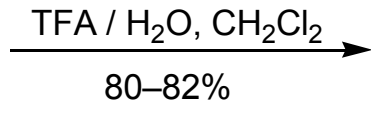<smiles>CCOC(=O)/C(=C/c1ccccc1)CC(=O)O</smiles>

13

$\mathrm{NEt}_{3}, \mathrm{Ac}_{2} \mathrm{O}$, heating $86-100 \%$<smiles>CCOC(=O)c1cc(OC(C)=O)c2ccccc2c1</smiles>

6

Scheme 5. Synthesis of $\mathbf{1 3}$ by cleavage of the tert-butylester in $\mathbf{5}$, of $\mathbf{6}$ by Friedel-Crafts acylation and of 14 by solvolysis.

The resulting acid $\mathbf{1 3}$ was used as crude product for the following Friedel-Crafts acylation; for this transformation the conventionally employed reagents $\mathrm{Ac}_{2} \mathrm{O}$ and $\mathrm{KOAc}$ or $\mathrm{NaOAc}^{21}$ were not suitable for the application in the microreactor due to the poor solubility of the salts in organic solvents. Looking for modifications we realized that the transformation is baseaccelerated. In the absence of a base using only $\mathrm{Ac}_{2} \mathrm{O}$ the desired product was not formed. Therefore, $\mathrm{NEt}_{3}$ was employed and proved to be more suitable than KOAc giving a yield of $86 \%-96 \%$ in the batch mode (Table 5). For the reaction in the microreactor the substrate 13 and $\mathrm{Ac}_{2} \mathrm{O}$ as well as $\mathrm{NEt}_{3}$ were premixed at room temperature and then pumped into the preheated microreactor $\left(130^{\circ} \mathrm{C}\right)$ by one inlet to give 6 with a yield of $100 \%$, while at lower temperatures (about $100^{\circ} \mathrm{C}$ ) only mixtures of the substrate and the product were observed (Table 5, entry 2 and 3).

Table 4. Synthesis of 13: [a] Crude product

\begin{tabular}{cccc}
\hline Entry & Solvent & Batch mode yield $^{[\mathrm{a}]}(t, T)$ & MR yield $^{[\mathrm{aa}]}(\tau, T)$ \\
\hline 1 & $\mathrm{CH}_{2} \mathrm{Cl}_{2}$ & $80 \%(16 \mathrm{~h}, \mathrm{rt})$ & $82 \%\left(5 \mathrm{~min}, 34^{\circ} \mathrm{C}\right)$ \\
\hline
\end{tabular}

The subsequent solvolysis of $\mathbf{6}$ was performed in the microreactor using $\mathrm{NaOEt}^{22}$ in catalytic amounts instead of $\mathrm{K}_{2} \mathrm{CO}_{3}$ as used in the batch mode. The best yield of almost $100 \%$ was achieved by using $30-\mathrm{mol} \%$ of NaOEt at $72^{\circ} \mathrm{C}$ for $23.5 \mathrm{~min}$ (Table 6, entry 3). With a smaller amount of NaOEt the reaction was incomplete under these conditions. However, it is also possible to obtain good results by using a lower flow rate with $20-\mathrm{mol} \%$ of $\mathrm{NaOEt}$ or less, while the reaction temperature can not be increased over $70^{\circ} \mathrm{C}$, since $\mathrm{EtOH}$ would then form gas 
bubbles, which is not desirable using a microreactor. The accelerating factor in the microreactor was estimated as about 3 .

Table 5. Synthesis of 6: [a] Crude product. [b] Isolated product after recrystallization from diethylether and pentane

\begin{tabular}{cccc}
\hline Entry & ${\text { Base in } \mathrm{Ac}_{2} \mathrm{O}}$ & Batch mode yield & \\
\hline 1 & $\mathrm{KOAc}^{\mathrm{a}]}(t, T)$ & MR yield $^{[\mathrm{a}]}(\tau, T)$ \\
2 & $\mathrm{NEt}_{3}$ & $78 \%\left(2.5 \mathrm{~h}, 136^{\circ} \mathrm{C}\right)$ & - \\
3 & $\mathrm{NEt}_{3}$ & $86-96 \%\left(3 \mathrm{~h}, 136^{\circ} \mathrm{C}\right)$ & $100 \%\left(47 \mathrm{~min}, 130^{\circ} \mathrm{C}\right)$ \\
& & $69 \%{ }^{[\mathrm{b}]}\left(7 \mathrm{~h}, 92^{\circ} \mathrm{C}\right)$ & mixture $\left(47 \mathrm{~min}, 95^{\circ} \mathrm{C}\right)$ \\
\hline
\end{tabular}

The protection of the naphthol $\mathbf{1 4}$ as its benzyl ether $\mathbf{7}$ could conventionally be achieved using $\mathrm{K}_{2} \mathrm{CO}_{3}$ as base in $89 \%$ yield (Table 7 , entry 1). To allow a homogeneous reaction mixture LiOEt and $(i \mathrm{Pr})_{2} \mathrm{NEt}^{23}$ were used as base, but under these conditions only an incomplete conversion was observed (entry 2 and 3), and with aqueous $\mathrm{NaOH}(>2.0$ eq) a mixture of the undesired acid $15^{24}$ und the desired product 16 was formed.

Table 6. Synthesis of 14: [a] Crude product. [b] In addition, 10\% of the starting material was found

\begin{tabular}{cccc}
\hline Entry & Base in EtOH & Batch mode yield $^{[\mathrm{a}]}(t, T)$ & MR yield $^{[\mathrm{a}]}(\tau, T)$ \\
\hline $1^{[21 \mathrm{a}]}$ & $\mathrm{K}_{2} \mathrm{CO}_{3}$ & $90 \%(15 \mathrm{~min}, \mathrm{reflux})$ & - \\
2 & $20-\mathrm{mol} \% \mathrm{NaOEt}$ & $98 \%\left(1 \mathrm{~h}, 78^{\circ} \mathrm{C}\right)$ & $87 \%{ }^{[\mathrm{b}]}\left(72^{\circ} \mathrm{C}, 23.5 \mathrm{~min}\right)$ \\
3 & $30-\mathrm{mol}^{\circ} \mathrm{NaOEt}$ & - & $100 \%\left(72^{\circ} \mathrm{C}, 23.5 \mathrm{~min}\right)$ \\
\hline
\end{tabular}

However, by using aqueous $\mathrm{NaOH}(1.2 \mathrm{eq})$, the phase transfer catalyst $\mathrm{TBABr}$ and the waterinsoluble organic solvent 2-methyltetrahydrofuran (MTHF), ${ }^{25}$ a liquid-liquid biphasic reaction in the micro-reactor gave the benzyl ether 7 in $72 \%$ yield within $31 \mathrm{~min}$ at $40^{\circ} \mathrm{C}$. As also observed on other occasions, microreactors are especially suitable for liquid-liquid biphasic reactions. ${ }^{3,26}$ 


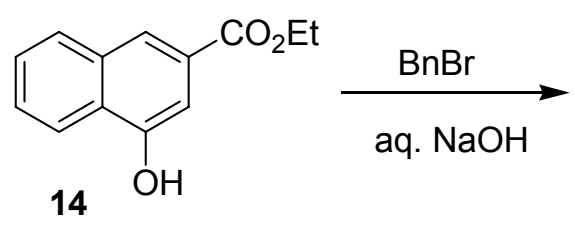<smiles>CCOC(=O)c1cc(OCc2ccccc2)c2ccccc2c1</smiles><smiles>O=C(O)c1cc(OCc2ccccc2)c2ccccc2c1</smiles>

Scheme 6. Synthesis of 7 by benzylation.

Table 7. Synthesis of 7: [a] Crude product. [b] Isolated product by column chromatography. In addition, $19 \%$ of the substrate 14 was reisolated. [c] In the batch mode $23-\mathrm{mol} \% \mathrm{TBABr}$ and in MR 40-mol\% TBABr were used. [d] Isolated product after recrystallization from ethanol

\begin{tabular}{cccc}
\hline Entry & Base & Batch mode yield $(t, T)$ & MR yield $(\tau, T)$ \\
\hline 1 & $\mathrm{~K}_{2} \mathrm{CO}_{3}$ & $89 \%^{[\mathrm{ad}]}(12.5 \mathrm{~h}, \mathrm{rt})$ & - \\
& $\mathrm{LiOEt}$ & $75 \%{ }^{[\mathrm{b}]}(30.5 \mathrm{~h}, \mathrm{rt})$ & - \\
3 & $(i \operatorname{Pr})_{2} \mathrm{NEt}$ & mixture $(3 \mathrm{~h}, \mathrm{rt})$ & - \\
& & then $\left.12 \mathrm{~h}, 50^{\circ} \mathrm{C}\right)$ & \\
$4^{[\mathrm{cc}]}$ & aq. $\mathrm{NaOH}(1.2 \mathrm{eq})$ & $70 \%{ }^{[\mathrm{dd}]}\left(40^{\circ} \mathrm{C}, 2 \mathrm{~h}\right)$ & $72 \%{ }^{[\mathrm{d}]}\left(40^{\circ} \mathrm{C}, 31 \mathrm{~min}\right)$ \\
\hline
\end{tabular}

For the hydrolysis of the ethyl ester 7 at first $\mathrm{LiOH}$ was used, which however formed a suspension and the reaction proceeded rather slowly (Table 8, entry 1). In contrast, using $\mathrm{NaOH}$ at elevated temperature the reaction was complete in the batch mode in a much shorter time (entry 2). Employing these biphasic conditions without the addition of a phase transfer catalyst in the microreactor, the acid 16 was obtained in $100 \%$ yield in 48 min at $68^{\circ} \mathrm{C}$.

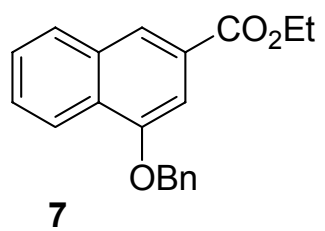

7

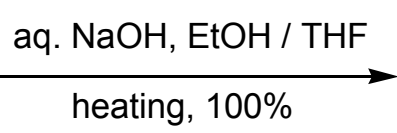

heating, $100 \%$<smiles>O=C(O)c1cc(OCc2ccccc2)c2ccccc2c1</smiles>

16

Scheme 7. Synthesis of $\mathbf{1 6}$ by hydrolysis. 
Table 8. Synthesis of 16: [a] Crude product

\begin{tabular}{cccc}
\hline Entry & Base & Batch mode yield ${ }^{[\mathrm{a}]}(t, T)$ & MR yield $^{[\mathrm{a}]}(\tau, T)$ \\
\hline 1 & $\mathrm{LiOH} \cdot \mathrm{H}_{2} \mathrm{O}$ & $92 \%(40 \mathrm{~h}, \mathrm{rt})$ & - \\
2 & aq. $\mathrm{NaOH}$ & $100 \%\left(3.5 \mathrm{~h}, 74^{\circ} \mathrm{C}\right)$ & $100 \%\left(48 \mathrm{~min}, 68^{\circ} \mathrm{C}\right)$ \\
\hline
\end{tabular}

The obtained carboxylic acid $\mathbf{1 6}$ was directly used for the reaction with the Shioiri-Yamada reagent (DPPA) ${ }^{27}$ in the presence of tert-butanol to give the desired final product 1 via a Curtius rearrangement. According to the proposed mechanism ${ }^{27 a}$ the intermediate azide $\mathbf{1 7}$ would lead to the isocyanate 18 which further reacts with tert-butanol to give 1 (Scheme 8). It was expected that the nitrogen formation in the Curtius rearrangement would have a negative influence on the steady state situation in the microreactor. Thus, for a reproducible reaction we prepared the isocyanate 18 using 1,4-dioxane as solvent in the batch mode. After the gas evolution had finished, the resulting solution was introduced into the microreactor together with tert-butanol containing a little of 1,4-dioxane. However, even under these conditions the obtained yield of $52 \%$ of 1 was much lower than those in the batch mode (Table 9). This seems to be a result of the instability of the isocyanate 18; we first thought that the use of molecular sieves in the batch mode, which are clearly unsuitable for reactions in the micro reactor, has caused the difference; but a reaction in the batch mode without the addition of molecular sieves gave the same results. ${ }^{12 b}$ It is noteworthy that a homogenous solution could be collected at the outlet of the microreactor, while the formation of a suspension was observed in the batch mode. This phenomenon can be explained by the finer size of the particles obtained in the microreactor.

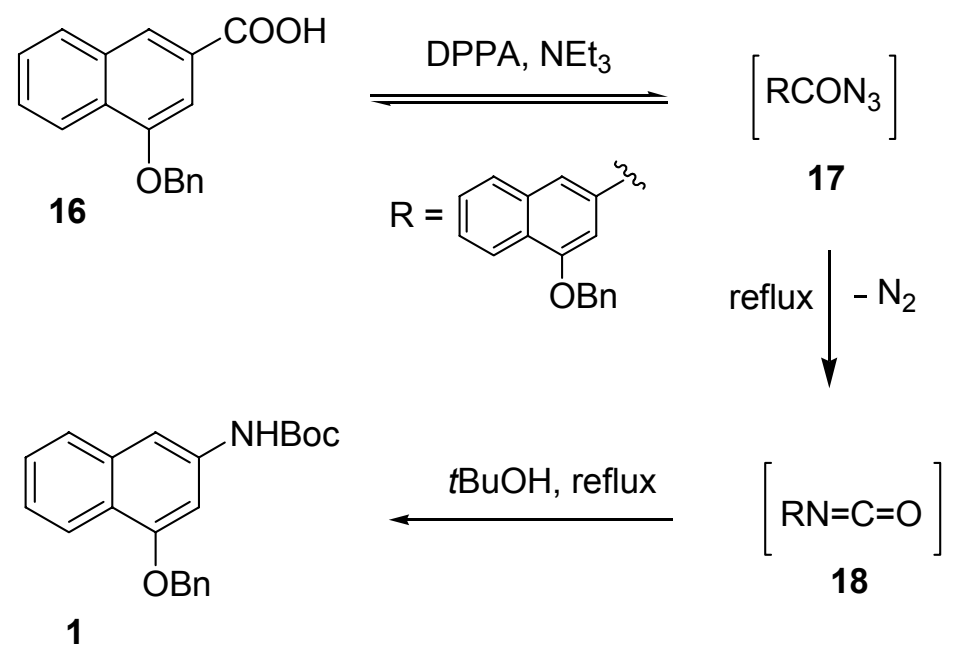

Scheme 8. Proposed Curtius rearrangement for the synthesis of $\mathbf{1}$. 
Table 9. Synthesis of $\mathbf{1}$ via Curtius rearrangement: [a] Crude product. [b] Formation of $\mathbf{1 8}$ in the batch mode followed by reaction with tert-butanol in the MR

\begin{tabular}{cccc}
\hline Entry & Additive & Batch mode yield ${ }^{[\mathrm{a}]}(t, T)$ & $\mathrm{MR}^{[\mathrm{b}]} \mathrm{yield}^{[\mathrm{a}]}(\tau, T)$ \\
\hline $1^{[12 \mathrm{a}]}$ & molecular sieve $4 \AA$ & $85 \%(72 \mathrm{~h}$, reflux $)$ & - \\
$2^{[12 \mathrm{~b}]}$ & no additive & $83 \%(3 \mathrm{~h}$, reflux $)$ & $52 \%\left(34 \mathrm{~min}, 80^{\circ} \mathrm{C}\right)$ \\
\hline
\end{tabular}

\section{Conclusions}

In conclusion, a nine-step synthesis of the aminonaphthalene $\mathbf{1}$ was accomplished using a microreactor as reaction vessel in a continuous-flow mode, allowing a large-scale production in an easier and safer way as in the batch mode. Moreover, an accelerating factor for the different reactions of $F=3-10$ and mostly similar and sometimes even better yields using the microreactor were found.

\section{Experimental Section}

General Procedures. All reagents obtained from commercial sources were normally used without further purification. All solvents were dried by standard methods. Thin-layer chromatography (TLC) was performed on precoated silica gel plates (SIL G/UV 254 , MachereyNagel GmbH \& Co. KG). Silica gel 60 (0.032-0.064 mm) (Merck) was used for column chromatography. ${ }^{1} \mathrm{H}-\mathrm{NMR}$ spectra were recorded on Varian mercury-200 or Unity-300. All reactions in the batch mode were performed in normal laboratory glassware. As microreactor the CYTOS $^{\circledR}$ College System (MR, CPC Systems) was used consisting of one micromixer (core structure) with $2 \mathrm{~mL}$ residence volume and a residence unit with $45 \mathrm{~mL}$ volume. The flow rates of $0.4-20 \mathrm{~mL} / \mathrm{min}$ were controlled by two integrated ISMATEC ceramic piston pumps. The temperature in the microreactor and the attached residence unit was regulated by an external thermostat (Lauda RKS-20 or Lauda Integral T1200). It was set at least $5^{\circ} \mathrm{C}$ lower than the boiling point of solvent used.

MR-Setup ${ }^{4,10 b, 13 c}$ : Before the reaction the MR was purged with the solvent used in the transformation (at least a 2-fold volume of the microreactor). The pumps A (for inlet A) and B (for inlet B) of the MR were calibrated to the desired flow rates. The residence time $\tau$ was defined by the equation: $\tau(\mathrm{min})=$ volume $(\mathrm{mL}) /$ total flow rate $(\mathrm{mL} / \mathrm{min})$. After preparation of the solution of the substrates (one or two) the transformation was started by pumping the solution(s) into the micromixer. Product collection started after at least 1.5-fold residence time to ensure steady state conditions. ${ }^{4,13 c}$ The accuracy of the flow rate was verified by measuring the consumed volume of the solutions of the substrates after a given time period. 
Procedure: Only the experiments with the best results in the batch mode and the MR are described.

Bromoacetic acid tert-butyl ester (4). Batch mode. Bromoacetyl bromide $(20.0 \mathrm{~mL}, 229 \mathrm{mmol}$, $1.00 \mathrm{eq})$ was added dropwise to a stirred solution of tert-butanol $(28.3 \mathrm{~mL}, 298 \mathrm{mmol}, 1.30 \mathrm{eq})$, $N, N$-dimethylaniline $(31.8 \mathrm{~mL}, 252 \mathrm{mmol}, 1.10 \mathrm{eq})$ in $\mathrm{DMF}(80 \mathrm{~mL})$ at $0^{\circ} \mathrm{C}$. Stirring was continued at $\mathrm{rt}$ for $19.5 \mathrm{~h}$ before water $(100 \mathrm{~mL})$ and chloroform $(200 \mathrm{~mL})$ were added. The aqueous layer was separated and extracted with chloroform $(2 \times 100 \mathrm{ml})$. The combined organic layers were washed with $10 \%$ sulfuric acid $(2 \times 150 \mathrm{~mL})$ and brine, dried $\left(\mathrm{MgSO}_{4}\right)$ and filtered. The solvent was removed and the residue distilled under reduced pressure to give $\mathbf{4}$ as a colorless liquid (27.8 g, 62\%). MR: Residence volume $47 \mathrm{~mL}, \tau=34 \mathrm{~min}, \mathrm{~T}=35^{\circ} \mathrm{C}$. Solution $\mathrm{A}$, bromoacetyl bromide $(50.0 \mathrm{~mL}, 572 \mathrm{mmol})$ in dry dichloromethane (total volume $100 \mathrm{~mL}$ ) was introduced into inlet $\mathrm{A}$ at a flow rate of $0.4 \mathrm{~mL} / \mathrm{min}$. Solution $\mathrm{B}, N, N$-dimethylaniline $(79.5 \mathrm{~mL}$, $629 \mathrm{mmol})$, tert-butanol $(70.7 \mathrm{~mL}, 744 \mathrm{mmol})$, DMAP $(7.00 \mathrm{~g}, 57.2 \mathrm{mmol})$ in DMF (total volume $260 \mathrm{~mL}$ ) was simultaneously introduced into inlet $\mathrm{B}$ at a flow rate of $1.0 \mathrm{~mL} / \mathrm{min}$. The product solution corresponding to $59 \mathrm{~mL}$ of used solution A was collected over $150 \mathrm{~min}$ beginning after a run time of $1.6 \tau$. It was treated with water $(150 \mathrm{~mL})$ and extracted with diethylether $(4 \times 80 \mathrm{~mL})$. The combined organic layers were washed with $10 \%$ aqueous sulfuric acid $(3 \times 100 \mathrm{~mL})$, an aqueous saturated $\mathrm{NaHCO}_{3}$-solution $(100 \mathrm{~mL})$ and brine, dried $\left(\mathrm{NaSO}_{4}\right)$ and filtered. The solvent was removed and the residue distillated under reduced pressure to give 4 as a colorless liquid (43.4 g, 66\%). ); b.p. $60^{\circ} \mathrm{C}$ at 20 mbar. ${ }^{1} \mathbf{H}-\mathbf{N M R}\left(200 \mathrm{MHz}, \mathrm{CDCl}_{3}\right): \delta=$ $1.48\left(\mathrm{~s}, 9 \mathrm{H}, \mathrm{C}\left(\mathrm{CH}_{3}\right)_{3}\right), 3.75\left(\mathrm{~s}, 2 \mathrm{H}, \mathrm{CH}_{2} \mathrm{Br}\right)$.

2-(Diethoxyphosphoryl)succinic acid 4-tert-butyl-1-ethyl diester (9). Batch mode. To a stirred solution of $n$-butyllithium $(2.5 \mathrm{M}$ in hexane, $90.0 \mathrm{~mL})$ in dry THF $(155 \mathrm{~mL})$ was added dropwise at $-78^{\circ} \mathrm{C}$ triethyl phosphonoacetate $(48.0 \mathrm{~g}, 214 \mathrm{mmol}, 1.00 \mathrm{eq})$ and stirring of the resulting yellow solution was continued at $\mathrm{rt}$ for $3 \mathrm{~h}$. Then a solution of 4 (44.1 g, $226 \mathrm{mmol}$, $1.05 \mathrm{eq})$ in dry THF $(18 \mathrm{~mL})$ was added dropwise at $0^{\circ} \mathrm{C}$. Stirring was continued at $\mathrm{rt}$ for $36 \mathrm{~h}$, then the solvent evaporated in vacuo and the residue carefully treated with EtOAc $(200 \mathrm{~mL})$ and water $(250 \mathrm{~mL})$ with cooling. The aqueous layer was separated and extracted with EtOAc $(2 \times$ $70 \mathrm{~mL})$. The combined organic layers were washed with water $(100 \mathrm{~mL})$ and brine, dried $\left(\mathrm{MgSO}_{4}\right)$ and filtered. After removal of the solvent the residue was distillated under reduced pressure to afford 9 as a colorless liquid (41.1 g, 57\%). MR: Residence volume $47 \mathrm{~mL}, \tau=24$ min, $\mathrm{T}=40^{\circ} \mathrm{C}$. Solution A, a yellow solution of the intermediate product 8 (total volume 332 $\mathrm{mL})$ prepared with $n$-butyllithium $(2.5 \mathrm{M}$ in hexane, $110 \mathrm{~mL})$, dry THF $(170 \mathrm{~mL})$ and triethyl phosphonoacetate $(58.7 \mathrm{~g}, 262 \mathrm{mmol})$ as described for the batch mode was introduced into inlet $\mathrm{A}$ at a flow rate of $1.56 \mathrm{~mL} / \mathrm{min}$. Solution $\mathrm{B}, 4$ in anhydrous THF (total volume $87 \mathrm{~mL}$ ) was simultaneously introduced into inlet $\mathrm{B}$ at a flow rate of $0.40 \mathrm{~mL} / \mathrm{min}$. The product solution corresponding to $57.5 \mathrm{~mL}$ of used solution B was collected over $150 \mathrm{~min}$ beginning from a run time of $1.7 \tau$. Work up and purification as described for the batch mode afforded 9 as a colorless liquid (41.9 g, 70\%); b.p. $143^{\circ} \mathrm{C}$ at 0.17 mbar. ${ }^{1} \mathbf{H}-\mathbf{N M R}\left(200 \mathrm{MHz}, \mathrm{CDCl}_{3}\right): \delta=1.24-1.38(\mathrm{~m}$, 
$\left.9 \mathrm{H}, 3 \times \mathrm{CH}_{2} \mathrm{CH}_{3}\right), 1.43\left(\mathrm{~s}, 9 \mathrm{H}, \mathrm{C}\left(\mathrm{CH}_{3}\right)_{3}\right), 2.72\left(\mathrm{ddd}, J=17.1,8.8,3.4 \mathrm{~Hz}, 1 \mathrm{H}, 3-\mathrm{H}_{\mathrm{a}}\right), 2.88-3.10$ (m, $1 \mathrm{H}, 2-\mathrm{H}), 3.40$ (ddd, $\left.J=23.9,11.8,3.4 \mathrm{~Hz}, 1 \mathrm{H}, 3-\mathrm{H}_{\mathrm{b}}\right), 4.03-4.35\left(\mathrm{~m}, 6 \mathrm{H}, 3 \times \mathrm{CH}_{2} \mathrm{CH}_{3}\right)$.

(E)-2-Benzylidenesuccinic acid 4-tert-butyl-1-ethyl diester (5). Batch mode. A solution of $\mathrm{NaOEt}$ (21\%wt, $2.30 \mathrm{~mL}, 6.16 \mathrm{mmol}, 1.04 \mathrm{eq})$ in EtOH was added slowly by syringe to a stirred solution of freshly distillated benzaldehyde $(659 \mathrm{mg}, 6.21 \mathrm{mmol}, 1.05 \mathrm{eq})$ and 9 (2.00 g, 5.91 $\mathrm{mmol}, 1.00 \mathrm{eq})$ in dry EtOH $(15 \mathrm{~mL})$ at $0^{\circ} \mathrm{C}$. After stirring for $15 \mathrm{~min}$ at $0^{\circ} \mathrm{C}$ stirring was continued at rt for $5 \mathrm{~h}$. The solvent was evaporated in vacuo and the residue taken up in EtOAc $(40 \mathrm{~mL})$ and water $(10 \mathrm{~mL})$. The organic layer was separated, washed with water $(10 \mathrm{~mL})$ and brine, dried $\left(\mathrm{MgSO}_{4}\right)$ and filtered. The solvent was removed in vacuo to provide $\mathbf{5}$ as a yellow oil (1.67 g, 97\%). MR: Residence volume $47 \mathrm{~mL}, \tau=47 \mathrm{~min}, \mathrm{~T}=25^{\circ} \mathrm{C}$. Solution A, a solution of 9 (16.3 g, $48.3 \mathrm{mmol})$ and freshly distillated benzaldehyde $(5.38 \mathrm{~g}, 50.7 \mathrm{mmol})$ in dry EtOH (total volume $70 \mathrm{~mL}$ ) was introduced into inlet A at a flow rate of $0.5 \mathrm{~mL} / \mathrm{min}$. Solution B, a NaOEtsolution in EtOH prepared by dilution of a NaOEt-solution (21\%wt $18.9 \mathrm{~mL}, 50.7 \mathrm{mmol})$ with dry $\mathrm{EtOH}$ to a total volume of $70 \mathrm{~mL}$, was simultaneously introduced into inlet $\mathrm{B}$ at a flow rate of $0.5 \mathrm{~mL} / \mathrm{min}$. The product solution corresponding to $10.5 \mathrm{~mL}, 10 \mathrm{~mL}$ and $15 \mathrm{~mL}$ of used solution A were successively collected over 21 min beginning from the run time of $1.0 \tau$, over 20 min beginning from the run time of $1.5 \tau$ and over 30 min beginning from the run time of $1.9 \tau$. Work up and purification as described for the batch mode provided $\mathbf{5}$ as a yellow oil (1.19 g, 57\%; $1.57 \mathrm{~g}, 78 \% ; 2.66 \mathrm{~g}, 89 \%$, respectively). ${ }^{1} \mathbf{H}-\mathbf{N M R}\left(200 \mathrm{MHz}, \mathrm{CDCl}_{3}\right): \delta=1.34(\mathrm{t}, J=$ $\left.7.1 \mathrm{~Hz}, 3 \mathrm{H}, \mathrm{OCH}_{2} \mathrm{CH}_{3}\right), 1.45\left(\mathrm{~s}, 9 \mathrm{H}, \mathrm{C}\left(\mathrm{CH}_{3}\right)_{3}\right), 3.45\left(\mathrm{~s}, 2 \mathrm{H}, 3-\mathrm{H}_{2}\right), 4.28(\mathrm{q}, J=7.1 \mathrm{~Hz}, 2 \mathrm{H}$, $\left.\mathrm{OC}_{2} \mathrm{CH}_{3}\right), 7.36(\mathrm{~s}, 5 \mathrm{H}, 5 \times \mathrm{Ph}-\mathrm{H}), 7.85(\mathrm{~s}, 1 \mathrm{H}, \mathrm{PhC} \underline{\mathrm{H}})$.

(E)-2-Benzylidene-succinic acid 1-ethyl ester (13). Batch mode. A mixture of $\mathrm{TFA} / \mathrm{H}_{2} \mathrm{O}(V / V$ $=9: 1$, total volume $62 \mathrm{~mL}$ ) was added to a stirred solution of 5 (13.1 g, $45.1 \mathrm{mmol}, 1.00 \mathrm{eq})$ in dichloromethane $(40 \mathrm{~mL})$ at $\mathrm{rt}$ and stirring was continued for $16 \mathrm{~h}$. The solvent was evaporated in vacuo and for azeotropic removal of TFA the residue was taken up in toluene and concentrated in vacuo again ( 3 times with $25 \mathrm{~mL}$ ). Then an aqueous saturated $\mathrm{NaHCO}_{3}$-solution $(48 \mathrm{~mL})$ was added carefully. After being stirred for $1 \mathrm{~h}$ the mixture was washed with pentane (2 $\times 30 \mathrm{~mL})$ and acidified to $\mathrm{pH} 1$ with $2 \mathrm{~N} \mathrm{HCl}(36 \mathrm{~mL})$. The resulting mixture was extracted with EtOAc $(2 \times 50 \mathrm{~mL})$ and the combined organic lagers were washed with brine, dried $\left(\mathrm{MgSO}_{4}\right)$, filtered and concentrated in vacuo to afford $\mathbf{1 3}$ as a pale yellow solid (8.42 $\mathrm{g}, 80 \%)$. MR: Residence volume $2 \mathrm{~mL}, \tau=5 \mathrm{~min}, \mathrm{~T}=34^{\circ} \mathrm{C}$. Solution A, a solution of $5(10.8 \mathrm{~g}, 37.2 \mathrm{mmol})$ in dichloromethane (total volume $35 \mathrm{~mL}$ ) was introduced into inlet $\mathrm{A}$ at a flow rate of $0.2 \mathrm{~mL} / \mathrm{min}$. Solution $\mathrm{B}$, a mixture of $\mathrm{TFA} / \mathrm{H}_{2} \mathrm{O}(V / V=9: 1$, total volume $45 \mathrm{~mL})$ was simultaneously introduced into inlet $\mathrm{B}$ at a flow rate of $0.2 \mathrm{~mL} / \mathrm{min}$. The product solution corresponding to 23.6 $\mathrm{mL}$ of used solution A was collected over 130 min beginning from a run time of $6 \tau$. Work up and purification as described for the batch mode afforded 13 as a pale yellow solid (3.73 g, 82\%). ${ }^{1} \mathbf{H}-\mathbf{N M R}\left(200 \mathrm{MHz}, \mathrm{CDCl}_{3}\right): \delta=1.35\left(\mathrm{t}, J=7.1 \mathrm{~Hz}, 3 \mathrm{H}, \mathrm{OCH}_{2} \mathrm{CH}_{3}\right), 3.58\left(\mathrm{~s}, 2 \mathrm{H}, 3-\mathrm{H}_{2}\right)$, $4.30\left(\mathrm{q}, J=7.1 \mathrm{~Hz}, 2 \mathrm{H}, \mathrm{OC}_{2} \mathrm{CH}_{3}\right), 7.28-7.49(\mathrm{~m}, 5 \mathrm{H}, 5 \times \mathrm{Ph}-\mathrm{H}), 7.93(\mathrm{~s}, 1 \mathrm{H}, \mathrm{PhC} \underline{\mathrm{H}})$, $11.12\left(\mathrm{~s}_{\mathrm{br}}, 1 \mathrm{H}, \mathrm{CO}_{2} \mathrm{H}\right)$. 
4-Acetoxy-naphthalene-2-carboxylic acid ethyl ester (6). Batch mode. A solution of 13 (35.2 $\mathrm{g}, 150 \mathrm{mmol}, 1.00 \mathrm{eq})$ in $\mathrm{Ac}_{2} \mathrm{O}(770 \mathrm{~mL})$ was stirred at $\mathrm{rt}$ for $16.5 \mathrm{~h}$. Then $\mathrm{NEt}_{3}(29.3 \mathrm{~mL}, 210$ mmol, $1.40 \mathrm{eq})$ was added and the mixture heated to reflux $\left(\mathrm{T}=136^{\circ} \mathrm{C}\right.$, oil bath: $\left.155^{\circ} \mathrm{C}\right)$ for $3 \mathrm{~h}$. The solvent was evaporated in vacuo and the residue taken up in EtOAc $(200 \mathrm{~mL})$ and water $(200 \mathrm{~mL})$. After basification to $\mathrm{pH}=9$ with solid $\mathrm{NaHCO}_{3}$ the aqueous layer was separated and extracted with EtOAc $(100 \mathrm{~mL})$. The combined organic layers were washed successively with an aqueous saturated $\mathrm{NaHCO}_{3}$-solution $(2 \times 150 \mathrm{~mL}), 2 \mathrm{~N} \mathrm{HCl}(2 \times 100 \mathrm{~mL})$ and brine, dried $\left(\mathrm{MgSO}_{4}\right)$, filtered and concentrated in vacuo to yield 6 as a brown solid $(37.3 \mathrm{~g}, 96 \%)$. MR: Residence volume $47 \mathrm{~mL}, \tau=47 \mathrm{~min}, \mathrm{~T}=130^{\circ} \mathrm{C}$. Solution $\mathrm{A}$, a solution of 13 in $\mathrm{Ac}_{2} \mathrm{O}$ (total volume $190 \mathrm{~mL})$ prepared by mixing a solution of $13(8.24 \mathrm{~g}, 35.2 \mathrm{mmol})$ in $\mathrm{Ac}_{2} \mathrm{O}(132 \mathrm{~mL})$ with a solution of $\mathrm{NEt}_{3}(4.98 \mathrm{~g}, 49.2 \mathrm{mmol}, 1.40 \mathrm{eq})$ in $\mathrm{Ac}_{2} \mathrm{O}(50 \mathrm{~mL})$, was introduced into inlet $\mathrm{A}$ at a flow rate of $1.0 \mathrm{~mL} / \mathrm{min}$. The product solution corresponding to $30 \mathrm{~mL}$ of used solution $\mathrm{A}$ was collected over $30 \mathrm{~min}$ beginning from a run time of $2 \tau$ and over $30 \mathrm{~min}$ from the run time of $2.6 \tau$. Work up and purification as described for the batch mode yielded $\mathbf{6}$ as a brown solid (1.45 g, 100\%; 1.44 g, 100\% respectively). ${ }^{1} \mathbf{H}-\mathbf{N M R}\left(200 \mathrm{MHz}, \mathrm{CDCl}_{3}\right): \delta=1.42(\mathrm{t}, J=7.1 \mathrm{~Hz}, 3 \mathrm{H}$, $\left.\mathrm{OCH}_{2} \underline{\mathrm{C}}_{3}\right), 2.46\left(\mathrm{~s}, 3 \mathrm{H}, \mathrm{COC}_{3}\right), 4.42\left(\mathrm{q}, J=7.1 \mathrm{~Hz}, 2 \mathrm{H}, \mathrm{OCH}_{2} \mathrm{CH}_{3}\right), 7.58\left(\mathrm{~m}_{\mathrm{c}}, 2 \mathrm{H}, 6-\mathrm{H}, 7-\right.$ H), $7.82(\mathrm{~d}, J=1.4 \mathrm{~Hz}, 1 \mathrm{H}, 3-\mathrm{H}), 7.83-7.90$ (m, $1 \mathrm{H}, 8-\mathrm{H}), 7.93-8.01$ (m, $1 \mathrm{H}, 5-\mathrm{H}), 8.50$ (s, 1 $\mathrm{H}, 1-\mathrm{H})$.

4-Hydroxy-naphthalene-2-carboxylic acid ethyl ester (14). Batch mode. A solution of NaOEt $(21 \% w t, 15.0 \mathrm{~mL}, 39.9 \mathrm{mmol}, 0.277 \mathrm{eq})$ in EtOH was added to a solution of 6 (37.3 g, 144 $\mathrm{mmol}, 1.00 \mathrm{eq})$ in dry EtOH $(1000 \mathrm{~mL})$. The mixture was heated to reflux $\left(\mathrm{T}_{\text {internal }}=78^{\circ} \mathrm{C}\right) \mathrm{using}$ an oil bath for $1 \mathrm{~h}$. After removal of the solvent in vacuo the resulting residue was taken up in EtOAc $(300 \mathrm{~mL})$ and washed with an aqueous saturated $\mathrm{NH}_{4} \mathrm{Cl}$-solution $(2 \times 100 \mathrm{~mL})$ and brine. The organic solution was dried $\left(\mathrm{MgSO}_{4}\right)$, filtered and concentrated in vacuo to furnish 14 as a brown solid (30.4 g, $141 \mathrm{mmol}, 98 \%$ ). $M R$ : Residence volume $47 \mathrm{~mL}, \tau=23.5 \mathrm{~min}, \mathrm{~T}=72^{\circ} \mathrm{C}$. Solution A, a solution of $6(5.24 \mathrm{~g}, 20.2 \mathrm{mmol})$ in dry $\mathrm{EtOH}$ (total volume $97 \mathrm{~mL}$ ) was introduced into inlet $\mathrm{A}$ at a flow rate of $1.0 \mathrm{~mL} / \mathrm{min}$. Solution $\mathrm{B}$, a NaOEt-solution in EtOH prepared by dilution of a NaOEt-solution $(21 \% \mathrm{wt}, 3.00 \mathrm{~mL}, 8.04 \mathrm{mmol})$ with dry EtOH to a total volume of $97 \mathrm{~mL}$, was simultaneously introduced into inlet B at a flow rate of $1.0 \mathrm{~mL} / \mathrm{min}$. The product solution corresponding to $40 \mathrm{~mL}$ of the used solution A was collected over $40 \mathrm{~min}$ beginning from a run time of $1.5 \tau$. Work up and purification as described for the batch mode furnished 14 as a brown solid $(1.81 \mathrm{~g}, 100 \%)$. ${ }^{1} \mathbf{H}-\mathbf{N M R}\left(200 \mathrm{MHz}, \mathrm{CDCl}_{3}\right): \delta=1.38(\mathrm{t}, J=7.2$ $\left.\mathrm{Hz}, 3 \mathrm{H}, \mathrm{OCH}_{2} \underline{\mathrm{CH}}_{3}\right), 4.38$ (q, $\left.J=7.2 \mathrm{~Hz}, 2 \mathrm{H}, \mathrm{OC}_{2} \mathrm{CH}_{3}\right), 6.42(\mathrm{~s}$ r $, 1 \mathrm{H}, \mathrm{OH}), 7.42-7.57$ (m, 3 H, 3-H, 6-H, 7-H), 7.79-7.89 (m, 1 H, 8-H), 8.13 (s, 1 H, 1-H), 8.15-8.22 (m, 1 H, 5-H).

4-Benzyloxy-naphthalene-2-carboxylic acid ethyl ester (7). Batch mode. To a stirred solution of 14 (0.52 g, $2.4 \mathrm{mmol}, 1.0 \mathrm{eq})$ in 2-methyltetrahydrofuran (MTHF, $10 \mathrm{~mL}$ ) were added benzyl bromide $(0.45 \mathrm{~g}, 2.6 \mathrm{mmol}, 1.1 \mathrm{eq})$, tetrabutylammonium bromide TBABr $(0.18 \mathrm{~g}, 0.56 \mathrm{mmol}$, $0.23 \mathrm{eq})$, water $(9 \mathrm{~mL})$ and an aqueous $2.5 \mathrm{M} \mathrm{NaOH}$-solution $(1.2 \mathrm{~mL}, 2.9 \mathrm{mmol}, 1.2 \mathrm{eq})$. The mixture was heated to $\mathrm{T}_{\text {internal }}=40^{\circ} \mathrm{C}$ for $2 \mathrm{~h}$. After cooling to room temperature the organic layer was separated, washed successively with $2 \mathrm{~N} \mathrm{HCl}(5 \mathrm{~mL})$, water $(5 \mathrm{~mL})$ and brine, dried 
$\left(\mathrm{MgSO}_{4}\right)$, filtered and concentrated in vacuo to afford a light brown-yellow solid $(0.69 \mathrm{~g})$, which was recrystallized from EtOH to give 7 as a light yellow solid $(0.53 \mathrm{~g}, 70 \%)$. MR: Residence volume $47 \mathrm{~mL}, \tau=31 \mathrm{~min}, \mathrm{~T}=40^{\circ} \mathrm{C}$. Solution $\mathrm{A}$, a solution of $14(3.5 \mathrm{~g}, 16 \mathrm{mmol})$ and benzyl bromide $(3.1 \mathrm{~g}, 18 \mathrm{mmol}$ ) in MTHF (total volume $60 \mathrm{~mL}$ ) was introduced into inlet A at a flow rate of $0.75 \mathrm{~mL} / \mathrm{min}$. Solution $\mathrm{B}$, a solution of $\operatorname{TBABr}(2.1 \mathrm{~g}, 6.4 \mathrm{mmol})$ and aqueous $2.5 \mathrm{M}$ $\mathrm{NaOH}(7.9 \mathrm{~mL}, 20 \mathrm{mmol}$ ) in water (total volume $60 \mathrm{~mL}$ ) was simultaneously introduced into inlet $\mathrm{B}$ at a flow rate of $0.75 \mathrm{~mL} / \mathrm{min}$. The product solution corresponding to $14 \mathrm{~mL}$ of used solution A was collected over 19 min beginning from a run time of $1.5 \tau$. Work up and purification as described for the batch mode gave 7 as a light yellow solid $(0.84 \mathrm{~g}, 72 \%)$. ${ }^{1} \mathbf{H}-$ NMR $\left(200 \mathrm{MHz}, \mathrm{CDCl}_{3}\right): \delta=1.46\left(\mathrm{t}, J=7.1 \mathrm{~Hz}, 3 \mathrm{H}, \mathrm{OCH}_{2} \mathrm{CH}_{3}\right), 4.45$ (q, $J=7.1 \mathrm{~Hz}, 2 \mathrm{H}$, $\left.\mathrm{OC}_{2} \mathrm{CH}_{3}\right), 5.31\left(\mathrm{~s}, 2 \mathrm{H}, \underline{\mathrm{C}}_{2} \mathrm{Ph}\right), 7.32-7.66(\mathrm{~m}, 8 \mathrm{H}, 3-\mathrm{H}, 6-\mathrm{H}, 7-\mathrm{H}, 5 \times \mathrm{Ph}-\mathrm{H}), 7.87-7.97$ (m, 1 $\mathrm{H}, 8-\mathrm{H}), 8.25$ (s, $1 \mathrm{H}, 1-\mathrm{H}), 8.32-8.42$ (m, $1 \mathrm{H}, 5-\mathrm{H})$.

4-Benzyloxy-naphthalene-2-carboxylic acid (16). Batch mode. An aqueous $2.5 \mathrm{M} \mathrm{NaOH}-$ solution $(9.10 \mathrm{~mL}, 22.8 \mathrm{mmol}, 10.0 \mathrm{eq})$ was added to a stirred solution of 7 (700 mg, $2.28 \mathrm{mmol}$, $1.00 \mathrm{eq})$ in THF $(6 \mathrm{~mL})$ and $\mathrm{EtOH}(8 \mathrm{~mL})$. The biphasic mixture was heated to reflux $\left(\mathrm{T}_{\text {internal }}=\right.$ $\left.74^{\circ} \mathrm{C}\right)$ in an oil bath $\left(80^{\circ} \mathrm{C}\right)$ for $3.5 \mathrm{~h}$. The solvent was evaporated and the residue acidified with $2 \mathrm{~N} \mathrm{HCl}(15 \mathrm{~mL})$. The formed precipitate was dissolved by addition of EtOAc $(50 \mathrm{~mL})$ and the aqueous layer was separated and extracted with EtOAc $(2 \times 15 \mathrm{~mL})$. The combined organic layers were washed with brine, dried $\left(\mathrm{MgSO}_{4}\right)$, filtered and concentrated in vacuo to give $\mathbf{1 6}$ as a pale yellow solid (634 mg, 100\%). 2) MR: The MR system was configured as follows: residence volume $47 \mathrm{~mL}, \tau=48 \mathrm{~min}, \mathrm{~T}=68^{\circ} \mathrm{C}$. Solution A, a solution of 7 (4.91 g, $\left.16.0 \mathrm{mmol}\right)$ in EtOH $(56 \mathrm{~mL})$ and THF $(42 \mathrm{~mL})$ with a total volume of $99 \mathrm{~mL}$ was introduced into inlet $\mathrm{A}$ at a flow rate of $0.58 \mathrm{~mL} / \mathrm{min}$. Solution $\mathrm{B}$, an aqueous solution of $\mathrm{NaOH}(2.5 \mathrm{M}, 64.0 \mathrm{~mL}, 160 \mathrm{mmol})$ was simultaneously introduced into inlet $\mathrm{B}$ at a flow rate of $0.40 \mathrm{~mL} / \mathrm{min}$. The product solution corresponding to $26 \mathrm{~mL}$ of used solution A was collected over $45 \mathrm{~min}$ beginning from a run time of $1.6 \tau$. Work up and purification as described for the batch mode gave $\mathbf{1 6}$ as a pale yellow solid $(1.19 \mathrm{~g}, 100 \%) .{ }^{1} \mathbf{H}-\mathbf{N M R}\left(300 \mathrm{MHz}, \mathrm{DMSO}_{\mathrm{d}}\right): \delta=5.38\left(\mathrm{~s}, 2 \mathrm{H}, \mathrm{CH}_{2} \mathrm{Ph}\right), 7.33-7.48(\mathrm{~m}, 3 \mathrm{H}, 1$ $\times \mathrm{Ph}-\mathrm{H}, 6-\mathrm{H}, 7-\mathrm{H}), 7.50(\mathrm{~d}, J=1.2 \mathrm{~Hz}, 1 \mathrm{H}, 3-\mathrm{H}), 7.55-7.70(\mathrm{~m}, 4 \mathrm{H}, 4 \times \mathrm{Ph}-\mathrm{H}), 8.05-8.12(\mathrm{~m}$, $1 \mathrm{H}, 8-\mathrm{H}), 8.23$ (s, $1 \mathrm{H}, 1-\mathrm{H}), 8.23-8.28$ (m, $1 \mathrm{H}, 5-\mathrm{H}), 13.01$ ( $\mathrm{s}$, $, 1 \mathrm{H}, \mathrm{COOH})$.

(4-Benzyloxy-naphthalen-2-yl)-carbamic acid tert-butyl ester (1). Batch mode. To a stirred solution of 16 (2.86 g, $10.3 \mathrm{mmol}, 1.00 \mathrm{eq})$ in dry 1,4-dioxane (60 mL) were added $\mathrm{NEt}_{3}(1.25 \mathrm{~g}$, $12.3 \mathrm{mmol}, 1.19 \mathrm{eq})$ and DPPA (3.06 g, $11.1 \mathrm{mmol}, 1.08 \mathrm{eq})$. The mixture was heated to reflux for $45 \mathrm{~min}$ with evolution of nitrogen to give the isocyanate $\mathbf{1 8}$ and afterwards cooled down to $40^{\circ} \mathrm{C}$. Then mixture was treated with freshly distillated tert-butanol $(192 \mathrm{~mL})$ and heated to reflux $\left(\mathrm{T}_{\text {internal }}=85^{\circ} \mathrm{C}\right)$ using an oil bath $\left(106^{\circ} \mathrm{C}\right)$ for $14 \mathrm{~h}$. After being cooled to room temperature the reaction mixture was filtered to remove a white precipitate. The mother liquor was treated with EtOAc $(120 \mathrm{~mL})$, washed successively with $2 \mathrm{~N} \mathrm{HCl}(2 \times 70 \mathrm{~mL})$, aqueous saturated $\mathrm{NaHCO}_{3}$-solution $(2 \times 40 \mathrm{~mL})$, water $(70 \mathrm{~mL})$ and brine $(60 \mathrm{~mL})$. The organic solution was dried $\left(\mathrm{MgSO}_{4}\right)$, filtered and concentrated in vacuo to provide a yellow solid $(3.03 \mathrm{~g})$ which was taken up in diethylether. Some insoluble white solid was filtered off through a sintered- 
glass-fritted funnel (porosity 4). The resulting mother liquor was concentrated in vacuo and the residue was washed with EtOH to give 1 a light yellow solid (1.49 g, 53\%). MR: Residence volume $47 \mathrm{~mL}, \tau=34 \mathrm{~min}, \mathrm{~T}=80^{\circ} \mathrm{C}$. Solution $\mathrm{A}$, a solution of the intermediate isocyanate 18 in 1,4-dioxane (total volume $100 \mathrm{~mL}$ ) prepared by heating the mixture of 16 (4.02 $\mathrm{g}, 14.4 \mathrm{mmol}$, $1.00 \mathrm{eq}), \mathrm{NEt}_{3}$ (1.75 g, $\left.17.3 \mathrm{mmol}, 1.20 \mathrm{eq}\right)$ and DPPA (4.19 g, $\left.15.2 \mathrm{mmol}, 1.06 \mathrm{eq}\right)$ in dry 1,4dioxane $(94 \mathrm{~mL})$ to reflux for $80 \mathrm{~min}$ and subsequent dilution with dry 1,4-dioxane, was introduced into inlet $\mathrm{A}$ at a flow rate of $0.40 \mathrm{~mL} / \mathrm{min}$. Solution B, a solution of dry tertbutanol/1,4-dioxane $(V / V=29: 1$, total volume $250 \mathrm{~mL})$ was simultaneously introduced into inlet $\mathrm{B}$ at a flow rate of $1.0 \mathrm{~mL} / \mathrm{min}$. The product solution corresponding relating to $47 \mathrm{~mL}$ of used solution A was collected over 120 min beginning from a run time of $1.8 \tau$. Work up and purification as described for the batch mode gave $\mathbf{1}$ as a light yellow solid $(1.21 \mathrm{~g}, 52 \%) .{ }^{1} \mathbf{H}-$ NMR $\left(200 \mathrm{MHz}, \mathrm{CDCl}_{3}\right): \delta=1.48\left(\mathrm{~s}, 9 \mathrm{H}, \mathrm{C}\left(\mathrm{CH}_{3}\right)_{3}\right), 5.15\left(\mathrm{~s}, 2 \mathrm{H}, \mathrm{C}_{2} \mathrm{Ph}\right), 6.55(\mathrm{~s}$ br $1 \mathrm{H}, \mathrm{NH})$, $6.99(\mathrm{~d}, J=1.7 \mathrm{~Hz}, 1 \mathrm{H}, 3-\mathrm{H}), 7.19-7.50$ (m, $8 \mathrm{H}, 1-\mathrm{H}, 6-\mathrm{H}, 7-\mathrm{H}, 5 \times \mathrm{Ph}-\mathrm{H}), 7.61(\mathrm{~d}, J=8.2 \mathrm{~Hz}$, $1 \mathrm{H}, 8-\mathrm{H}), 8.15$ (d, $J=8.2 \mathrm{~Hz}, 1 \mathrm{H}, 5-\mathrm{H})$.

\section{Acknowledgements}

This research was supported by the Deutsche Forschungsgemeinschaft and the Fonds der Chemische Industrie. We thank CPC-Systems for chemical and technical assistance.

\section{References}

1. (a) Mason, B. P.; Price, K. E.; Steinbacher, J. L.; Bogdan, A. R.; McQuade, D. T. Chem. Rev. 2007, 107, 2300. (b) Hartung, A.; Keane, M. A.; Kraft, A. J. Org. Chem. 2007, 72, 10235. (c) Sahoo, H. R.; Kralji, J. G.; Jensen, K. F. Angew. Chem. In. Ed. 2007, 46, 5704. (d) Jähnisch, K.; Hessel, V.; Löwe, H.; Baerns, M. Angew. Chem. Int. Ed. 2004, 43, 406. (e) Fletcher, P. D. I.; Haswell, S. J.; Pombo-Villar, E.; Warrington, B. H.; Watts, P.; Wong, S. Y. F.; Zhang, X. Tetrahedron 2002, 58, 4735.

2. (a) Hessel, V.; Hardt, S.; Löwe, H.; Schönfeld, F. AIChE J. 2003, 49, 566. (b) Song, H.; Tice, J. D.; Ismagilov, R. F. Angew. Chem. Int. Ed. 2003, 42, 767. (c) Taghavi-Moghadam, S.; Kleemann, A.; Golbig, K. G. Org. Process Res. Dev. 2001, 5, 652.

3. (a) Hisamoto, H.; Saito, T.; Tokeshi, M.; Hibara, A.; Kitamori, T. Chem. Comm. 2001, 2662.

4. Panke, G.; Schwalbe, T.; Stirner, W.; Taghavi-Moghadam, S.; Wille, G. Synthesis 2003, 2827.

5. (a) Usutani, H.; Tomida, Y.; Nagaki, A.; Okamoto, H.; Nokami, T.; Yoshida, J. J. Am. Chem. Soc. 2007, 129, 3406. (b) Kawaguchi, T.; Miyata, H.; Ataka, K.; Mae, K.; Yoshida, J. 
Angew. Chem. Int. Ed. 2005, 44, 2413. (c) Nagaki, A.; Togai, M.; Suga, S.; Aoki, N.; Mae, K.; Yoshida, J. J. Am. Chem. Soc. 2005, 127, 11666.

6. (a) Anderson, N. G. Org. Process Res. Dev. 2001, 5, 613. (b) Jas, G.; Kirschning, A. Chem. Eur. J. 2003, 9, 5708.

7. (a) Bayer, T.; Himmler, K. Chem. Eng. Technol. 2005, 28, 285. (b) Markowz, G.; Schirrmeister, S.; Albrecht, J.; Becker, F.; Schütte, R.; Caspary, K. J.; Klemm, E. Chem. Eng. Technol. 2005, 28, 459. (c) Chambers, R. D.; Fox, M. A.; Holling, D.; Nakano, T.; Okazoe, T.; Sandford, G. Chem. Eng. Technol. 2005, 28, 344. (d) Hessel, V.; Hofmann, C.; Löwe, H.; Meudt, A.; Scherer, S.; Schönfeld, F.; Werner, B. Org. Process Res. Dev. 2004, 8, 511. (e) Wakami, H.; Yoshida, J. Org. Process Res. Dev. 2005, 9, 787. (f) Haswell, S. J.; Watts, P. Green Chem. 2003, 5, 240.

8. (a) Geyer, K.; Codée, J. D. C.; Seeberger, P. H. Chem. Eur. J. 2006, 12, 8434. (b) Wörz, O.; Jäckel, K.; Richter, T.; Wolf, A. Chem. Eng. Technol. 2001, 24, 138.

9. (a) Roberge, D. M.; Ducry, L.; Bieler, N.; Cretton, P.; Zimmermann, B. Chem. Eng. Technol. 2005, 28, 318-323. (b) Jensen, K. F. Chem. Eng. Sci. 2001, 56, 293.

10. (a) Flögel, O.; Codée, J. D. C.; Seebach, D.; Seeberger, P. H. Angew. Chem. Int. Ed. 2006, 45, 7000. (b) Schwalbe, T.; Kadzimirsz, D.; Jas, G. QSAR Comb. Sci. 2005, 24, 758. (c) Schwalbe, T.; Taghavi-Moghadam, S.; Rüger, R. Eur. Pat. Appl. EP 1160241-A2, 2001.

11. (a) Tietze, L. F.; Major, F.; Schuberth, I.; Spiegl, D. A.; Krewer, B.; Maksimenka, K.; Bringmann, G.; Magull, J. Chem. Eur. J. 2007, 13, 4396. (b) Tietze, L. F.; Major, F.; Schuberth, I. Angew. Chem. Int. Ed. 2006, 45, 6574.

12. (a) Major, F. Dissertation, University of Göttingen, 2006. (b) Chen, X. Dissertation, University of Göttingen, 2007; see also other syntheses of analogs of compound 1. (c) Boger, D. L.; McKie, J. A.; Cai, H.; Cacciari, B.; Baraldi, P. G. J. Org. Chem. 1996, 61, 1710. (d) Boger, D. L.; Han, N.; Tarby, C. M.; Boyce, C. W.; Cai, H.; Jin, Q.; Kitos, P. A. J. Org. Chem. 1996, 61, 4894. (e) Jia, G.; Lown, J. W. Bioorg. Med. Chem. 2000, 8, 1607.

13. CYTOS $^{\circledR}$ microreactor system was developed by CPC-Systems (Schwalbe, T.; Golbig, K.; Hohmann, M.; Georg, P.; Oberbeck, A.; Dittmann, B.; Stasna, J.; Oberbeck, S. Eur. Pat. Appl. EP 1123734, 2001) and its features was introduced in Ref. [2c]. See also its application for chemical synthesis: (a) Acke, D. R. J.; Stevens, C. V. Org. Process Res. Dev. 2006, 10, 417. (b) Liu, S.; Fukuyama, T.; Sato, M.; Ryu, I. Org. Process Res. Dev. 2004, 8, 477. (c) Zhang, X.; Stefanick, S.; Villani, F. J. Org. Process Res. Dev. 2004, 8, 455. (d) Ref. [4]

14. (a) Abramovitch, B.; Shivers, J. C.; Hudson, B. E.; Hauser, C. R. J. Am. Chem. Soc. 1943, 65, 986. (b) Vollmar, A.; Dunn, M. S. J. Org. Chem. 1960, 25, 387.

15. Schneider, D. F.; Viljoen, M. S. Synth. Commun. 2002, 32, 721.

16. (a) Gallagher, P. T.; Hicks, T. A.; Lightfoot, A. P.; Owton, W. M. Tetrahedron Lett. 1994, 35, 289. (b) Owton, W. M.; Gallagher, P. T.; Juan-Montesinos, A. Synth. Commun. 1993, 23, 2119. 
17. (a) Rathke, M. W.; Nowak, M. J. Org. Chem. 1985, 50, 2624. (b) Blanchette, M. A.; Choy, W.; Davis, J. T.; Essenfeld, A. P.; Masamune, S.; Roush, W. R.; Sakai, T. Tetrahedron Lett. 1984, 25, 2183.

18. (a) Wadsworth, W. S.; Emmons, W. D. J. Am. Chem. Soc. 1961, 83, 1733-1738. (b) Boutagy, J.; Thomas, R. Chem. Rev. 1974, 74, 87.

19. Linke, S.; Kurz, J.; Lipinski, D.; Gau, W. Liebigs Ann. Chem. 1980, 542.

20. Mehta, A.; Jaouhari, R.; Benson, T. J.; Douglas, K. T. Tetrahedron Lett. 1992, 33, 5441.

21. (a) Boger, D. L.; Turnbull, P. J. Org. Chem. 1998, 63, 8004. (b) Comber, M. F.; Sargent, M. V. J. Chem. Soc. Perkin Trans. 1 1991, 2783. (c) Hughes, A. B.; Sargent, M. V. J. Chem. Soc. Perkin Trans. 1 1989, 449. (d) Rizzacasa, M. A.; Sargent, M. V. Aust. J. Chem. 1987, 40, 1737. (e) Borsche, W. Justus Liebigs Ann. Chem. 1936, 526, 1.

22. (a) Couladouros, E. A.; Strongilos, A. T. Eur. J. Org. Chem. 2002, 3341. (b) Howell, F. H.; Taylor, D. A. H. J. Chem. Soc. 1956, 4252.

23. (a) Adams, S. P.; Whitlock, H. W. J. Org. Chem. 1981, 46, 3474. (b) Roush, W. R.; Coffey, D. S.; Madar, D. J. J. Am. Chem. Soc. 1997, 119, 11331. (c) Roush, W. R.; Madar, D. J. Tetrahedron Lett. 1993, 34, 1553.

24. ${ }^{1} \mathbf{H}-\mathbf{N M R}\left(200 \mathrm{MHz}, \mathrm{DMSO}-\mathrm{d}_{6}\right)$ of the literature-known compound $\mathbf{1 5}: \delta=7.36$ (s, $1 \mathrm{H}, 3-$ H), 7.49-7.62 (m, 2 H, 6-H, 7-H), 7.94-8.02 (m, 1 H, 8-H), 8.04 (s, 1 H, 1-H), 8.11-8.21 (m, $1 \mathrm{H}, 5-\mathrm{H}), 10.37$ (s, $1 \mathrm{H}, \mathrm{OH}), 12.78\left(\mathrm{~s}_{\mathrm{br}}, 1 \mathrm{H}, \mathrm{CO}_{2} \mathrm{H}\right)$.

25. Ripin, D. H. B.; Vetelino, M. Synlett 2003, 2353.

26. (a) Ahmed, B.; Barrow, D.; Wirth, T. Adv. Synth. Catal. 2006, 348, 1043. (b) Ueno, M.; Hisamoto, H.; Kitamori, T.; Kobayashi, S. Chem. Comm. 2003, 936.

27. (a) Ninomiya, K.; Shioiri, T.; Yamada, S. Tetrahedron 1974, 30, 2151. (b) Shioiri, T.; Ninomiya, K.; Yamada, S. J. Am. Chem. Soc. 1972, 94, 6203. 